\section{Year-round Greenhouse Production of Cut Sunflowers in the Rocky Mountain West}

\author{
Andrea R. Garfinkel ${ }^{1}$ and Karen L. Panter ${ }^{2,3}$
}

ADDITIONAL INDEX wORDs. containerized, Helianthus annuus, photoperiod, Wyoming

Summary. The objective of this study was to determine the potential for year-round greenhouse production of specialty cut sunflowers (Helianthus annuus) in Wyoming. Over a 14-month period, we produced cut sunflowers in a nontraditional, transplant-based, potted method using natural light intensity and daylength conditions in Laramie, WY. Three cultivars of annual sunflowers, Dafna, ProCut Bicolor, and Sunbright Supreme, were grown from seeds sown at 2 -week intervals starting on 16 Nov. 2011. Each planting consisted of four replications of four plants each. Seedlings were transplanted into $550-\mathrm{mL}$ square plastic pots 15 days after sowing and were placed on greenhouse benches in blocks according to sow date. Flowers were cut at soil level when ray florets opened. Data collected included days to harvest and stem length for each stem. Results indicated significant cultivar by sow date interactions for days to harvest and stem lengths, indicating the importance of cultivar selection. Mean days to harvest ranged from $\mathbf{5 7}$ days ('Sunbright Supreme') to 103 days ('ProCut Bicolor'). Mean stem lengths ranged from $43 \mathrm{~cm}$ ('Dafna') to $153 \mathrm{~cm}$ ('Sunbright Supreme'). Overall, the results of this study show potential for year-round production of cut sunflowers and can help guide producers in the Rocky Mountain west to choose cultivars that best fit the needs of their business and market demand.

$\longrightarrow$ ut sunflowers are desirable and available nearly yearround (Nau, 2011) but are especially popular in the fall and summer months (Wien, 2009b; Yañez et al., 2012). Sunflowers are quite popular as fresh cut flowers yearround, largely due to the array of colors and growth habits now available (Dole and Wilkins, 1999; Nau, 2011). They are also easy to grow from seeds and have a relatively short cropping time, 60 to $70 \mathrm{~d}$, depending on the cultivar (Armitage and Laushman, 2008). These characteristics make sunflowers an ideal niche, locally grown crop for greenhouse crop producers who, particularly in Wyoming, may be a state away from a cut flower wholesaler.

The potential for year-round production of cut sunflowers has been investigated in other states and countries such as Hawaii (Criley, 2007), New York (Wien, 2006, 2007, 2012a, 2012b), Italy (Gimelli et al.,

Department of Plant Sciences, Department 3354, University of Wyoming, 1000 East University Avenue, Laramie, WY 82071

Funds for this project were provided through the Wyoming Department of Agriculture and the USDA's Specialty Crop Block Grant Program.

${ }^{1}$ Former Graduate Student

${ }^{2}$ Horticulture Specialist

${ }^{3}$ Corresponding author. E-mail: kpanter@uwyo.edu.
2003), The Netherlands (Blacquière et al., 2002), and Japan (Hayata and Imaizumi, 2000; Yañez et al., 2004, 2005). Studies concerning yearround production are of interest because, although many cultivars are day neutral, photoperiod may affect flowering of some cultivars (Hayata and Imaizumi, 2000; Wien, 2006, 2007, 2012a, 2012b; Yañez et al., 2004, 2005). Although studies on year-round sunflower production have been conducted in other regions, they took place under climatic conditions quite different from those found in the Rocky Mountain west; local climate has been shown to be a major factor in cut sunflower production (Ferguson et al., 2012; FernándezMartinez et al., 2009; Schuster, 1985 ). In fact, many of these studies, with the exception of those done in Hawaii and Italy, were conducted using photoperiodic lighting. Because of Wyoming's elevation, high intensity sunlight is abundant [average elevation $6700 \mathrm{ft}$ (Western Regional Climate Center, 2014)] and growing under our natural light conditions could be beneficial to growers who do not have access to supplemental and/or photoperiodic lighting or as a way to conserve energy and save on production costs.

The objective of this study was to quantify the changes in stem length and days to harvest in three sunflower cultivars grown continuously over a 14 -month period of time in a greenhouse production system that can be easily integrated into the current capabilities of the majority of Wyoming greenhouses, many of which are not currently producing cut flowers and may not have access to cut flower benches or lighting capabilities.

\section{Materials and methods}

Greenhouse experiments were conducted at the University of Wyoming Laramie Research and Extension Center greenhouse complex in Laramie, WY (lat. $44^{\circ} 45^{\prime} 30^{\prime \prime} \mathrm{N}$, long. $108^{\circ} 46^{\prime} 36^{\prime \prime} \mathrm{W}$, elevation $7200 \mathrm{ft}$ ). The section used in these studies contained mesh growing benches oriented east-west and aligned from north to south. The temperature set points were $70 / 60{ }^{\circ} \mathrm{F}$ (day/night). Plants were grown under natural light and daylengths to better understand their normal growth characteristics under our natural light conditions.

Environmental data were collected from 6 Mar. 2012 to 11 Apr. 2013 using pendant temperature/ light data loggers (64K-UA-002-64 $\mathrm{HOBO}$; Onset Computer Corp., Bourne, MA) placed $52 \mathrm{~cm}$ above the surface of the bench to track variations in light intensity, photoperiod, and air temperature. Environmental monitors were placed in the center of each one of the seven bench locations in the greenhouse; the southern bench contained five data

\begin{tabular}{llll}
\hline $\begin{array}{l}\text { Units } \\
\text { To convert U.S. to SI, } \\
\text { multiply by }\end{array}$ & U.S. unit & SI unit & $\begin{array}{l}\text { To convert SI to U.S., } \\
\text { multiply by }\end{array}$ \\
\hline 29.5735 & $\mathrm{fl} \mathrm{oz}$ & $\mathrm{mL}$ & 0.0338 \\
0.3048 & $\mathrm{ft}$ & $\mathrm{m}$ & 3.2808 \\
2.54 & inch $(\mathrm{es})$ & $\mathrm{cm}$ & 0.3937 \\
10.7639 & lumen $/ \mathrm{ft}^{2}$ & $\mathrm{~lx}$ & 0.0929 \\
28.3495 & $\mathrm{Oz}$ & $\mathrm{g}$ & 0.0353 \\
$\left({ }^{\circ} \mathrm{F}-32\right) \div 1.8$ & ${ }^{\circ} \mathrm{F}$ & ${ }^{\circ} \mathrm{C}$ & $\left({ }^{\circ} \mathrm{C} \times 1.8\right)+32$
\end{tabular}


Table 1. Differences among bench location temperature and light levels in seven locations on two benches used for fresh cut sunflower production in a greenhouse in Laramie, WY. Data were collected every $4 \mathrm{~h}$ beginning at midnight from 6 Mar. 2012 through 11 Apr. 2013, using pendant temperature/ light data loggers (64K-UA-002-64 HOBO; Onset Computer Corp., Bourne, MA). Means were calculated using a one-factor analysis of variance.

\begin{tabular}{lcc}
\hline Location no. & Mean temp $\left({ }^{\circ} \mathbf{F}\right)^{\mathbf{z}}$ & Mean light levels $\left(\text { lumens } / \mathrm{ft}^{2}\right)^{\mathbf{z}}$ \\
\hline 1 & $67.4 \mathrm{ab}^{\mathrm{y}}$ & $2,648.4 \mathrm{a}$ \\
2 & $66.6 \mathrm{c}$ & $1,998.6 \mathrm{~b}$ \\
3 & $66.6 \mathrm{c}$ & $2,272.6 \mathrm{ab}$ \\
4 & $67.3 \mathrm{~b}$ & $2,259.9 \mathrm{ab}$ \\
5 & $67.9 \mathrm{a}$ & $2,405.2 \mathrm{a}$ \\
6 & $67.5 \mathrm{ab}$ & $2,073.0 \mathrm{ab}$ \\
7 & $67.8 \mathrm{ab}$ & $1,639.4 \mathrm{c}$ \\
\hline
\end{tabular}

${ }^{2}\left({ }^{\circ} \mathrm{F}-32\right) \div 1.8={ }^{\circ} \mathrm{C}, 1$ lumen $/ \mathrm{ft}^{2}=10.7639 \mathrm{~lx}$

${ }^{{ }^{\prime}}$ Means with different letters within columns are significantly different at $P \leq 0.05$ using Fisher's least significant difference test. loggers and the northern bench two. Data were recorded every $4 \mathrm{~h}$ starting at midnight. Average temperatures ranged from 66.6 to $67.9^{\circ} \mathrm{F}$ (Table 1 ). Light readings averaged 1639.4 to 2648.4 lumens $/ \mathrm{ft}^{2}$ (Table 1 ).

Three cultivars of fresh cut sunflowers, Dafna, ProCut Bicolor, and Sunbright Supreme, were chosen for this study based on brown and gold flower color, single stem characteristic, and stem lengths (Harris Seeds, Rochester, NY).

Sowings began on 16 Nov. 2011 and continued every 2 weeks until 12 Dec. 2012. Seeds were sown into 128-cell plug trays in germination media (Seed Germination Mix; Conrad Fafard, Agawam, MA) and placed

Table 2. Mean days to harvest and stem lengths of sunflowers by cultivar and seed sow date as recorded in a greenhouse in Laramie, WY. Means were calculated using a randomized complete-block design two-factor factorial analysis of variance where one factor was cultivar and one factor was sow date. Photoperiod was recorded throughout the duration of sunflower production (from sowing to last harvest) for each sow date.

\begin{tabular}{|c|c|c|c|c|c|c|c|}
\hline \multirow[b]{2}{*}{ Sow date } & \multirow[b]{2}{*}{ Photoperiod $(\mathrm{h})^{\mathrm{z}}$} & \multicolumn{2}{|c|}{ 'Dafna' } & \multicolumn{2}{|c|}{ 'ProCut Bicolor' } & \multicolumn{2}{|c|}{ 'Sunbright Supreme' } \\
\hline & & $\begin{array}{c}\text { Mean time to } \\
\text { harvest }(\mathrm{d})\end{array}$ & $\begin{array}{c}\text { Mean stem } \\
\text { length }(\mathrm{cm})^{\mathrm{y}}\end{array}$ & $\begin{array}{c}\text { Mean time to } \\
\text { harvest }(\mathrm{d})\end{array}$ & $\begin{array}{l}\text { Mean stem } \\
\text { length }(\mathrm{cm})\end{array}$ & $\begin{array}{c}\text { Mean time to } \\
\text { harvest }(\mathrm{d})\end{array}$ & $\begin{array}{l}\text { Mean stem } \\
\text { length }(\mathrm{cm})\end{array}$ \\
\hline 30 Nov. 2011 & $<12$ & $72 \mathrm{e}$ & $61 \mathrm{i}$ & 97 ef & $117 \mathrm{fg}$ & $72 \mathrm{~g}$ & $77 \mathrm{~lm}$ \\
\hline 14 Dec. 2011 & $<12$ & $69 \mathrm{ef}$ & $53 \mathrm{kl}$ & 99 def & $133 \mathrm{~cd}$ & $69 \mathrm{~h}$ & 64 op \\
\hline 28 Dec. 2011 & $<12$ & $63 \mathrm{hi}$ & $55 \mathrm{jk}$ & 99 cdef & $136 \mathrm{bc}$ & $64 \mathrm{jk}$ & $72 \mathrm{mn}$ \\
\hline 8 Feb. 2012 & $<12$ & $59 \mathrm{jk}$ & $62 \mathrm{i}$ & $94 \mathrm{~h}$ & $141 \mathrm{ab}$ & $57 \mathrm{~m}$ & $76 \mathrm{~m}$ \\
\hline 22 Feb. 2012 & $<12$ & $58 \mathrm{k}$ & $75 \mathrm{~h}$ & 100 bcde & $143 \mathrm{a}$ & $58 \mathrm{~lm}$ & $89 \mathrm{ij}$ \\
\hline 7 Mar. 2012 & $\leq 12$ & $61 \mathrm{ij}$ & $81 \mathrm{~g}$ & $93 \mathrm{~h}$ & $136 \mathrm{bc}$ & $63 \mathrm{k}$ & $101 \mathrm{fg}$ \\
\hline 21 Mar. 2012 & $\leq 12$ & $71 \mathrm{e}$ & $102 \mathrm{f}$ & 93 hi & $131 \mathrm{~cd}$ & $74 \mathrm{fg}$ & $118 \mathrm{e}$ \\
\hline 4 Apr. 2012 & $\leq 12$ & $83 \mathrm{~b}$ & $133 \mathrm{a}$ & $85 \mathrm{j}$ & $143 \mathrm{a}$ & $90 \mathrm{a}$ & $153 \mathrm{a}$ \\
\hline 18 Apr. 2012 & 12 to 16 & $82 \mathrm{~b}$ & $119 \mathrm{~cd}$ & $75 \mathrm{~lm}$ & 114 ghi & $88 \mathrm{a}$ & $138 \mathrm{bc}$ \\
\hline 13 June 2012 & $\geq 16$ & $77 \mathrm{~cd}$ & $117 \mathrm{~d}$ & $67 \mathrm{n}$ & $107 \mathrm{~lm}$ & $77 \mathrm{de}$ & $137 \mathrm{c}$ \\
\hline 27 June 2012 & $\geq 16$ & $77 \mathrm{~cd}$ & $125 \mathrm{~b}$ & 67 no & $101 \mathrm{~m}$ & $81 \mathrm{bc}$ & $144 \mathrm{~b}$ \\
\hline 11 July 2012 & $\geq 16$ & $75 \mathrm{~d}$ & $120 \mathrm{bcd}$ & 65 no & 112 hijkl & $80 \mathrm{bcd}$ & $124 \mathrm{~d}$ \\
\hline 19 July 2012 & $\geq 16$ & $71 \mathrm{e}$ & $82 \mathrm{~g}$ & $64 \mathrm{o}$ & $88 \mathrm{n}$ & 76 ef & $102 \mathrm{f}$ \\
\hline 8 Aug. 2012 & 12 to 16 & $68 \mathrm{f}$ & $72 \mathrm{~h}$ & $74 \mathrm{~lm}$ & $92 n$ & $68 \mathrm{hi}$ & $86 \mathrm{jk}$ \\
\hline 22 Aug. 2012 & $\leq 12$ & $64 \mathrm{~h}$ & $83 \mathrm{~g}$ & $86 \mathrm{j}$ & $110 \mathrm{ijkl}$ & $64 \mathrm{jk}$ & 94 hi \\
\hline 5 Sept. 2012 & $\leq 12$ & $63 \mathrm{hi}$ & $73 \mathrm{~h}$ & 99 def & $140 \mathrm{ab}$ & 66 hij & $96 \mathrm{gh}$ \\
\hline 23 Oct. 2012 & $\leq 12$ & $68 \mathrm{fg}$ & $49 \mathrm{~lm}$ & $101 \mathrm{abcd}$ & $111 \mathrm{ijkl}$ & $66 \mathrm{hij}$ & $54 \mathrm{q}$ \\
\hline 31 Oct. 2012 & $\leq 12$ & $68 \mathrm{fg}$ & $53 \mathrm{kl}$ & $103 \mathrm{ab}$ & $125 \mathrm{e}$ & $68 \mathrm{hij}$ & 67 no \\
\hline 14 Nov. 2012 & $\leq 12$ & $68 \mathrm{ef}$ & $43 \mathrm{~m}$ & $103 \mathrm{a}$ & $109 \mathrm{jkl}$ & $65 \mathrm{ijk}$ & $51 \mathrm{q}$ \\
\hline 28 Nov. 2012 & $\leq 12$ & $65 \mathrm{gh}$ & $44 \mathrm{~m}$ & $102 \mathrm{abc}$ & $92 \mathrm{n}$ & $64 \mathrm{jk}$ & $54 \mathrm{q}$ \\
\hline 12 Dec. 2012 & $\leq 12$ & $65 \mathrm{~h}$ & $54 \mathrm{kl}$ & 99 def & $129 \mathrm{de}$ & $63 \mathrm{k}$ & $61 \mathrm{p}$ \\
\hline
\end{tabular}

${ }^{\mathrm{z}} \mathrm{A}$ range in hours indicates a change in photoperiod during production for that sow date.

${ }^{\mathrm{y}} \mathrm{l} \mathrm{cm}=0.3937$ inch

${ }^{x}$ Means with different letters within columns are significantly different at $P \leq 0.05$ using Fisher's least significant difference test. 


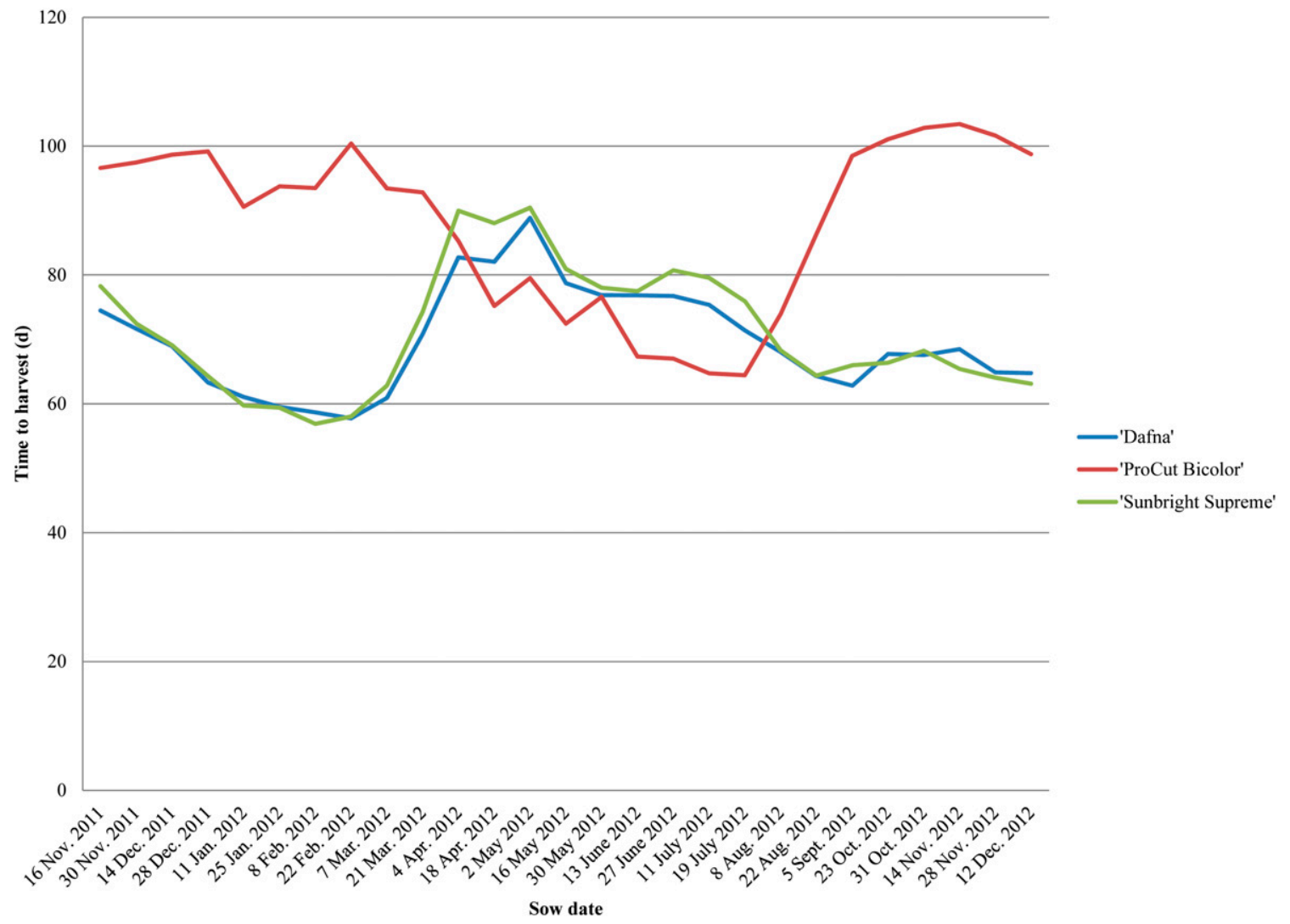

Fig. 1. Time to harvest of three cultivars of greenhouse-grown fresh cut sunflowers (Dafna, ProCut Bicolor, and Sunbright Supreme) over a 14-month period in Laramie, WY. Data were analyzed using a one-factor analysis of variance.

on a misting bench with temperatures set at $70 / 65^{\circ} \mathrm{F}$ (day/night). Misting was controlled with an automated clock system (Solar 3B; Schaefer Ventilation Equipment, Sauk Rapids, $\mathrm{MN}$ ). The mist system was set to trigger on for $20 \mathrm{~s}$ for every 20 solar units collected where one solar unit is equal to $0.02 \mathrm{M} \cdot \mathrm{m}^{-2}$. Extra seeds from a fourth cultivar, Sunrich Gold (Harris Seeds), were sown on the same schedule and were used as edge rows.

Three deviations from this schedule occurred on 19 Sept. 2012, 3 Oct. 2012, and 17 Oct. 2012. Rodent damage prevented the successful germination of seedlings from these sowings so revisions to the schedule were made. The first two sowings mentioned were not replanted due to failure to eliminate rodent problems, whereas the last sowing was replanted on 23 Oct. 2012. Sowings resumed as per the original schedule on 31 Oct. 2012.

Fifteen days after sowing, seedlings were transplanted into $550-\mathrm{mL}$ square plastic pots filled with professional grower's mix (Metro Mix 900; Sun Gro Horticulture Canada,
Vancouver, BC, Canada). Four replications of four plants each were used per cultivar per sow date. Replicates were blocked from north to south on each growing bench to eliminate variation due to light levels across the bench. Consecutive plantings were arranged east to west on one of seven designated locations across the two greenhouse benches used in this study; planting locations 1 through 5 were on the south bench and 6 and 7 on the north bench. Cultivars from a given sow date were randomly arranged within each bench location. An edge row of 'Sunrich Gold' was placed around the entire perimeter of the greenhouse benches to mitigate edge effects.

Growing-on methods were similar to those recommended in Nau (2011). Plants were watered by hand twice daily, until water drained from the bottom of each container. Fertilization occurred $13 \mathrm{~d}$ following transplant, upon the development of the second set of true leaves, with a topdressing of $2.5 \mathrm{~g}$ of $15 \mathrm{~N}-$ 4.4P-9.9K controlled-release fertilizer (Osmocote Plus 15-9-12, 5 to
6 month release rate; Scotts MiracleGro Co., Marysville, $\mathrm{OH}$ ).

Plants were staked $13 \mathrm{~d}$ following transplant using a bamboo stake and plant ties. Additionally, the plants were supported by a double layer of plastic floral caging. The caging was raised throughout the study to ensure sturdy, straight stems (Armitage and Laushman, 2008; Dole and Wilkins, 1999; Nau, 2011).

Flowers were considered ready for harvest after all of the ray florets were open but before the disk florets were open (Dole and Wilkins, 1999). Sunflowers were harvested about every other day. Stems were cut at soil level, and days to harvest and stem lengths were immediately recorded. Stem length was measured from the soil level to the base of the receptacle.

Experimental design was a twofactor factorial analysis of variance set within a randomized complete-block design. The two factors were sow date (27 dates) and cultivar (three cultivars). To determine if there was a relationship between stem length (response) and days to harvest (explanatory 


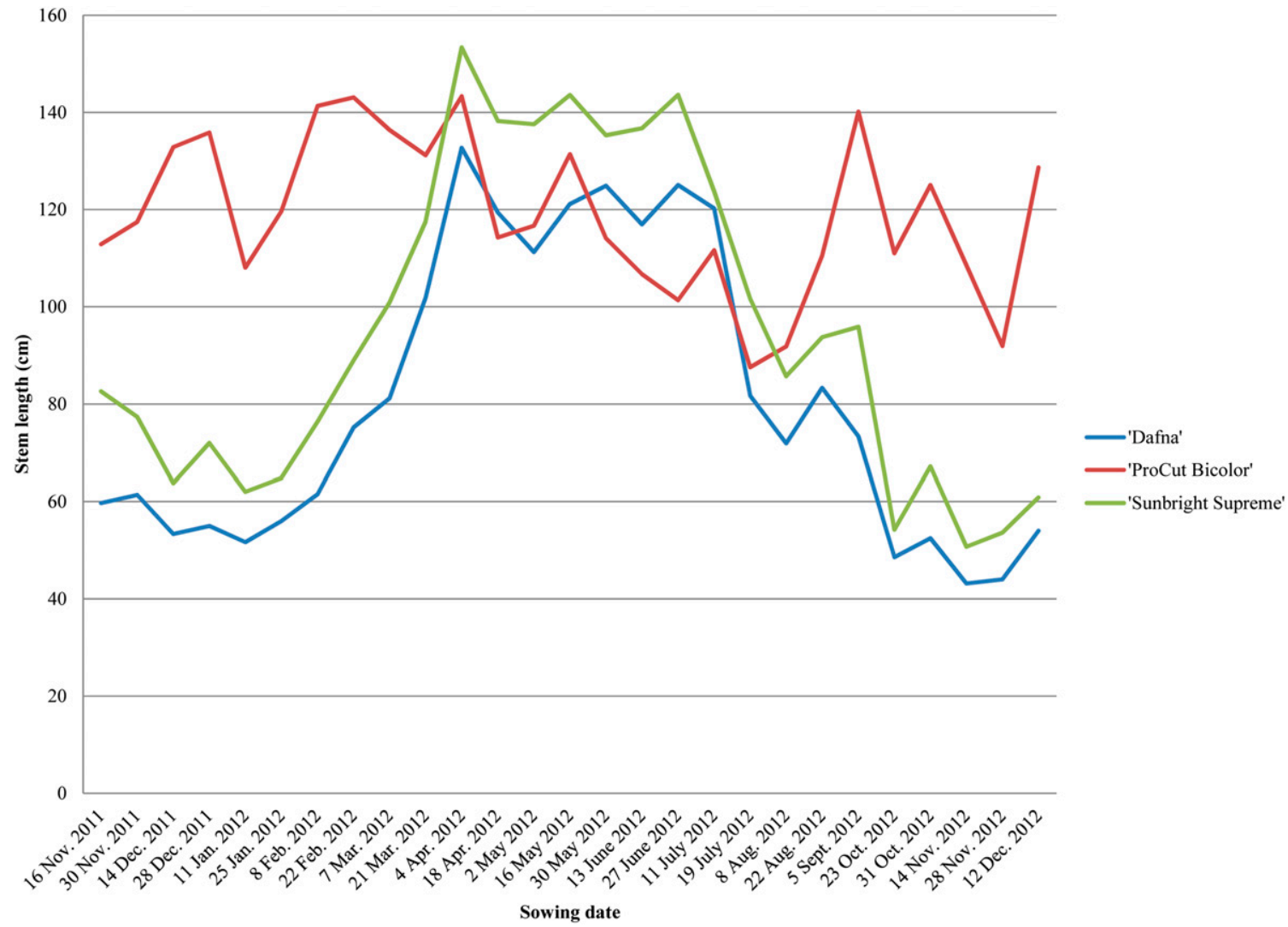

Fig. 2. Stem lengths of three cultivars of greenhouse-grown fresh cut sunflowers (Dafna, ProCut Bicolor, and Sunbright Supreme) over a 14-month period in Laramie, WY. Data were analyzed using a one-factor analysis of variance; $1 \mathrm{~cm}=0.3937 \mathrm{inch}$.

variable), linear regression analysis was used. Only sunflowers of saleable quality were used in data analyses. We determined saleable stems to be at least $40 \mathrm{~cm}$ as there are no industry standards for sunflower stem length. Standards are typically set by growers, buyers, or both (J.M. Dole, personal communication). Any distorted or misshapen flowers were excluded as well. Saleable yield was calculated by dividing the number of harvested stems by the total number planted of that cultivar. Data from 16 Nov. 2011 to 12 Dec. 2012 biweekly sow dates were used in the analysis. First harvest occurred 6 Mar. 2012 and last harvest was 11 Apr. 2013. Light and temperature were analyzed in a one-factor analysis of variance where the factor of bench location was tested to determine the effect on either temperature or light. All statistical computations were facilitated using SAS (version 9.3; SAS Institute, Cary, NC).

\section{Results}

Some significant differences in temperatures were found among the seven data logger locations likely due to the large number of data points collected over 14 months (Table 1 ). Light readings recorded by the data loggers over the same time frame were significantly different among the seven locations as well (Table 1 ). The lowest readings came from data logger no. 7, which was on the northern of the two benches used, toward the west side.

Saleable yields for each cultivar overall were $89 \%$ for Dafna, $91 \%$ for ProCut Bicolor, and 91\% for Sunbright Supreme (data not shown).

There was a significant cultivar by sow date interaction for both days to harvest and stem length (Table 2). The divergent results from 'ProCut Bicolor' were the cause of the significant interaction between cultivar and sow date for both days to harvest and stem length as 'Dafna' and 'Sunbright Supreme' showed similar tendencies over the 14-month trial period (Figs. 1 and 2).

Across all sow dates, mean days to harvest ranged from $57 \mathrm{~d}$ ('Sunbright Supreme') to $103 \mathrm{~d}$ ('ProCut Bicolor'). Mean stem lengths ranged from $43 \mathrm{~cm}$ ('Dafna') to $153 \mathrm{~cm}$ ('Sunbright Supreme') (Table 2, Figs. 1 and 2).

The fewest average days to harvest occurred in late January through February for 'Dafna' (58-60 d) and for 'Sunbright Supreme' (57-59 d). 'ProCut Bicolor' had the fewest average days to harvest from mid-June through mid-July sowings (64-67 d). The greatest average days to harvest for 'Dafna' was from a May sowing (89 d). 'Sunbright Supreme' had the greatest number of days to harvest from sowings that occurred in early April through early May (88-90 d). 'ProCut Bicolor' had the greatest number of days to harvest in late October through November (101103 d) (Table 2, Fig. 1).

'Dafna' and 'Sunbright Supreme' both had the tallest mean stem lengths from a sowing that took place in April. For 'Dafna', the tallest average stem length was $133 \mathrm{~cm}$ and for 'Sunbright Supreme,' the tallest average stem length was $153 \mathrm{~cm}$ (Table 2, Fig. 2). 'ProCut Bicolor' had the tallest average stem lengths from sowings that occurred in 

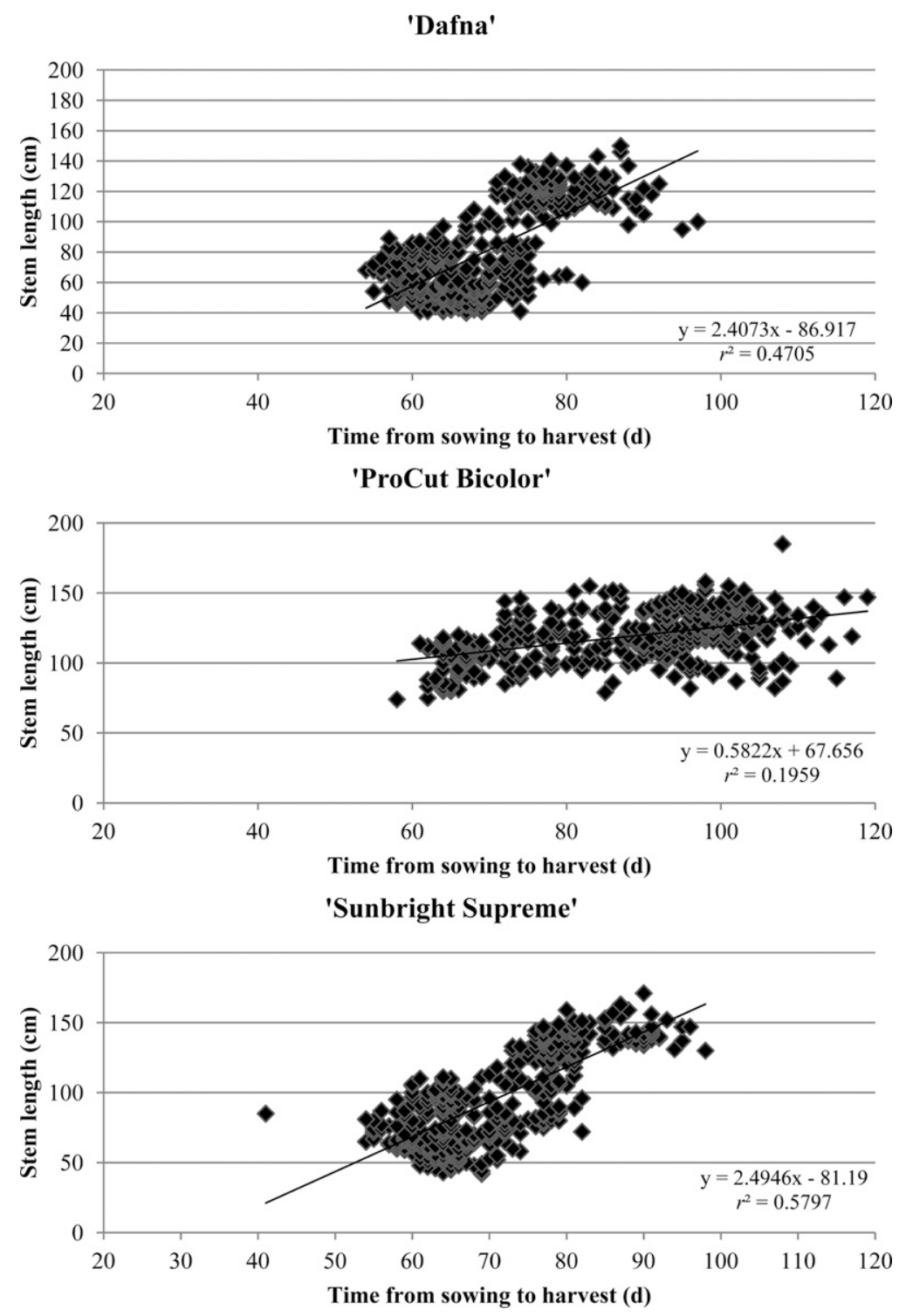

Fig. 3. Scatterplots of linear regression relationship between days from sowing to harvest (explanatory variable) and stem length (response) for three cut sunflower cultivars (Dafna, ProCut Bicolor, and Sunbright Supreme) grown over a 14-month period in a greenhouse in Laramie, WY; $1 \mathrm{~cm}=0.3937 \mathrm{inch}$.

February, April, and September $(140-143 \mathrm{~cm})$. The shortest average stem lengths for 'Dafna' were from sowings that took place in October through December $(43-56 \mathrm{~cm})$, 'Sunbright Supreme' had the shortest average stem lengths from October and November sowings (51-54 $\mathrm{cm}$ ), and 'ProCut Bicolor' had the shortest average stem lengths from sowings that took place in July, August, and November $(88-92 \mathrm{~cm})$ (Table 2, Fig. 2).

For 'Dafna' and 'Sunbright Supreme,' days to harvest moderately predicted stem length (Fig. 3). However, days to harvest did not predict stem length for 'ProCut Bicolor' (Fig. 3).

\section{Discussion}

The statistically different temperatures recorded were most likely not biologically important (Table 1 ). The average difference among the seven data loggers was only $1.3^{\circ} \mathrm{F}$, indicating little temperature variation between the two benches and seven data logger locations.

Light levels were also significantly different among the seven data logger locations. The lowest average readings were recorded by no. 7 , which was the northwestern growing location. There is the probability this particular data logger was shaded by other nearby plant material more so than the other six data loggers.

Significant interactions between time of year and cultivar for stem length and days to harvest were likely associated with changing photoperiods and the different responses to photoperiod displayed by the three cultivars. Different responses of sunflower cultivars to photoperiod are well documented (Blacquière et al., 2002; Gimelli et al., 2003; Hayata and Imaizumi, 2000; Schuster, 1985; Wien, 2009b; Yañez et al., 2004, 2005, 2012).

Data collected on 'Dafna' and 'Sunbright Supreme' stem lengths are consistent with the research conducted by Wien (2012b) that showed these cultivars to be facultative short-day crops. During short days, these two cultivars had the shortest stem lengths and the fewest days to harvest. The response of 'ProCut Bicolor' to $\geq 16$-h photoperiods also followed the conclusions from Wien $(2012 b)$. This cultivar displayed a facultative long-day response with the most days from sowing to harvest for harvests with photoperiods meeting or exceeding $16 \mathrm{~h}$. The stem length of 'ProCut Bicolor' was not strongly influenced by photoperiod.

Days to harvest for all three cultivars exceeded those reported by Wien (2012b). Days to harvest exceeded those reported in Wien (2012b) by $13 \mathrm{~d}$ for 'Sunbright Supreme' and $35 \mathrm{~d}$ for 'ProCut Bicolor.' Also, stem lengths in our study were shorter for 'Dafna' and 'ProCut Bicolor' than Wien (2012b). Our photoperiods were not controlled and were not exactly $12 \mathrm{~h}$ or $16 \mathrm{~h}$, which may help explain variations in days to harvest and stem lengths between our study and Wien's (2012b). Furthermore, the differences may be attributed to differences in climate between New York and Wyoming.

While some of the shortest stem lengths and days to harvest for 'ProCut Bicolor' are from long-day photoperiods, the high amount of variability within the same photoperiod suggests that there are other factors besides light that determine the growth habits of this cultivar, more so than 
in 'Dafna' or 'Sunbright Supreme'. The high amount of variability in the production of 'ProCut Bicolor' in terms of stem length was also observed in year-round studies conducted in Hawaii (Criley, 2007). Variability could be explained by the findings from Wien (2009a) that 'ProCut Bicolor' is only 'slightly sensitive' to long days (Wien, 2009a). As in this study, Criley (2007) was not able to attribute variability in this cultivar to light. Criley (2007) determined that irrigation played a large factor in affecting stem length and days to harvest. During this study, especially in short-day photoperiods, containers of 'ProCut Bicolor' seemed to dry out more quickly than either 'Dafna' or 'Sunbright Supreme'. It is possible that the variability in days to harvest and stem length was caused by the high potential for water stress due to root bound conditions. Pallez et al. (2002) hypothesized that sunflowers in containerized production can dry out quickly and affect sunflower height. The variability in stem length within photoperiod did not seem to be as great in 'Dafna' or 'Sunbright Supreme'; therefore, results could also be attributed to the idiosyncrasies of the cultivars.

\section{Conclusions}

Cultivars Dafna, ProCut Bicolor, and Sunbright Supreme were successfully cultivated year-round in a greenhouse environment in Laramie, WY. Unlike other studies of cut sunflowers where photoperiod was tightly controlled, we were able to elucidate variations in days to harvest and stem lengths under natural light conditions in the Rocky Mountain west. This study indicates that there is promising potential for the year-round production of fresh cut sunflowers using containers in the Rocky Mountain states, which can easily be integrated into virtually any greenhouse operation. However, there were marked differences in terms of days to harvest and stem length throughout the year. 'Dafna' and 'Sunbright Supreme' displayed a facultative short-day response, whereas
'ProCut Bicolor' showed a slight facultative long-day response. The different tendencies of these cultivars in terms of days to harvest and stem length mean that careful cultivar selection throughout the year is essential to maximize production efficiency and profit margins for growers who do not have access to or choose not to use photoperiodic controls. For example, a grower may choose to take 'ProCut Bicolor' out of production during the winter months due to its long time from sowing to harvest. Growers may also choose to use supplemental or photoperiodic lighting during some times of years to maximize the production of certain cultivars. Ultimately, the best production practices and cultivars for an operation will be dictated by the needs and markets of the individual operation. The results of this study can provide guidelines for producers to choose cultivars and production practices that best fit their businesses.

\section{Literature cited}

Armitage, A.M. and J.M. Laushman. 2008. Specialty cut flowers: The production of annuals, perennials, bulbs and woody plants for fresh and dry cut flowers. Varsity Press, Portland, OR.

Blacquière, T., N. Straver, and D. van den Berg. 2002. Possibilities for using photoperiodism to program flowering of sunflowers (Helianthus annums) in the greenhouse and in the open. Acta Hort. 580:101-109.

Criley, R.A. 2007. Year-round production of cut sunflower in Hawaii. HortScience 42:1015-1016.

Dole, J.M. and H.F. Wilkins. 1999. Floriculture: Principles and species. Prentice Hall, Upper Saddle River, NJ.

Ferguson, C.G., P.G. Vuppalapati, M.J. Stone, and E. Gray. 2012. Evaluation of cultivars of sunflowers (Helianthus annuus L.) and selected environments for production of cut flowers. J. Kentucky Acad. Sci. 73:90-95.

Fernández-Martinez, J.M., B. PérezVich, and L. Velasco. 2009. Sunflower, p. 155-232. In: J. Vollman and I. Rajcan (eds.). Oil crops. Vol. 4. Springer Sci. Business Media, New York, NY.
Gimelli, F., A. Leporati, and L. Maggiora. 2003. The all year round cultivation of cut sunflower in San Remo district. Acta Hort. 614:553-560.

Hayata, Y. and Y. Imaizumi. 2000. Effect of photoperiod on flower bud development of ornamental sunflowers. J. Jpn. Soc. Hort. Sci. 69:708-710.

Nau, J. (ed.). 2011. Helianthus, p. 436437. In: Ball red book. Vol. 2. 18th ed. Ball Publ., West Chicago, IL.

Pallez, L.C., J.M. Dole, and B.E. Whipker. 2002. Production and postproduction studies with potted sunflowers. HortTechnology 12:206-210.

Schuster, W.H. 1985. Helianthus annums, p. 98-121. In: A.H. Havley (ed.). CRC handbook of flowering. Vol. 3. CRC Press, Boca Raton, FL.

Western Regional Climate Center. 2014. Climate of Wyoming. 7 Aug. 2014. <http://www.wrcc.dri.edu/narratives/ WYOMING.htm>.

Wien, H.C. 2006. Growing black-eyed susan and sunflower out of season. Growing for Market 15:17-18.

Wien, H.C. 2007. Day-neutral sunflowers: Do they exist, and what difference does it make? Cut Flower Qrtly. 19:48-49.

Wien, H.C. 2009a. Daylength response of sunflowers. Dept. of Hort., Cornell Univ. Ithaca, NY.

Wien, H.C. 2009b. Floral crop production in high tunnels. HortTechnology 19:56-60.

Wien, H.C. 2012a. Cut flower cultural practice studies and variety trials, 2012. Dept. of Hort., Cornell Univ. Ithaca, NY.

Wien, H.C. 2012b. Sunflower seedling daylength response. Dept. of Hort., Cornell Univ. Ithaca, NY.

Yañez, P., S. Chinone, R. Hirohata, J. Ohno, and K. Ohkawa. 2012. Effects of time and duration of short-day treatments under long-day conditions on flowering of a quantitative short-day sunflower (Helianthus annums L.) 'Sunrich Orange' Sci. Hort. 140:8-11.

Yañez, P., H. Ohno, and K. Ohkawa. 2004. Effect of photoperiod on flowering and growth of ornamental sunflower cultivars. Envrion. Control Biol. 42:287-293.

Yañez, P., H. Ohno, and K. Ohkawa. 2005. Photoperiodic response and vase life of ornamental sunflower cultivars. HortTechnology 15:386-390. 